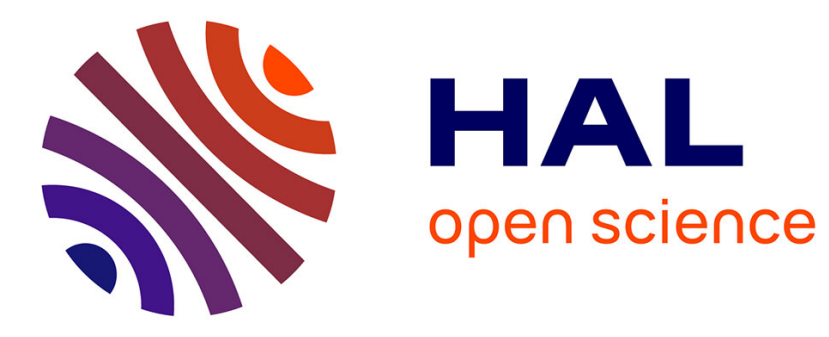

\title{
Design, complexing and catalytic properties of phosphorus thiazoles and benzothiazoles: a concise overview
}

Jean Pierre Majoral, Maria Zablocka, Marek Koprowski, Aurélien Hameau, Xiangyang Shi, Serge Mignani, Anne-Marie Caminade

\section{To cite this version:}

Jean Pierre Majoral, Maria Zablocka, Marek Koprowski, Aurélien Hameau, Xiangyang Shi, et al.. Design, complexing and catalytic properties of phosphorus thiazoles and benzothiazoles: a concise overview. New Journal of Chemistry, 2019, 43 (43), pp.16785-16795. 10.1039/C9NJ02966D . hal02360721

\section{HAL Id: hal-02360721 \\ https://hal.science/hal-02360721}

Submitted on 2 Nov 2020

HAL is a multi-disciplinary open access archive for the deposit and dissemination of scientific research documents, whether they are published or not. The documents may come from teaching and research institutions in France or abroad, or from public or private research centers.
L'archive ouverte pluridisciplinaire HAL, est destinée au dépôt et à la diffusion de documents scientifiques de niveau recherche, publiés ou non, émanant des établissements d'enseignement et de recherche français ou étrangers, des laboratoires publics ou privés. 


\title{
Design, complexing and catalytic properties of phosphorus thiazoles and benzothiazoles: A concise overview
}

Received 00th January 20xx, Accepted 00th January 20xx

DOI: $10.1039 / x 0 x x 00000 x$

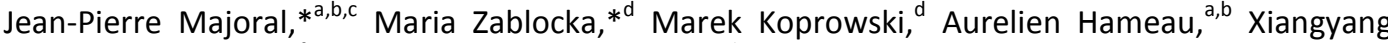 \\ Shi, ${ }^{e}$ Serge Mignani ${ }^{c, f, g}$ and Anne-Marie Caminade ${ }^{a, b}$
}

\begin{abstract}
The versatile functionalization of thiazoles and benzothiazoles at different locations in their backbone offers the possibility to design many substituted heterocyclic derivatives bearing active groups for applications in coordination chemistry, catalysis, and medicinal chemistry. The grafting of various phosphorus groups (phosphines, phosphine oxides, phosphonates, phosphinic acids, etc.) via different strategies leads to many phosphorus thiazoles and benzothiazoles acting per se as catalysts for a number of reactions for complexation with metals as $\mathrm{Ir}, \mathrm{Au}, \mathrm{Pt}, \mathrm{Pd}, \mathrm{Cu}$, for which the catalytic properties

were

investigated.
\end{abstract}

\section{Introduction}

Many applications of heterocycles bearing thiazoles and benzothiazoles as core structure and related derivatives were pointed out in different areas such as medicinal chemistry, coordination chemistry and catalysis.

Some of these biologically active entities were used, for example, for the treatment of inflammation, ${ }^{1}$ bacterial infections, $^{2}$ allergies, ${ }^{3}$ hypertension, ${ }^{4}$ insomnia, ${ }^{5}$ schizophrenia, ${ }^{6}$ or as new inhibitors of bacteria growth: DNA gyraseB subunit ${ }^{7}$ as well as fibrinogen receptor antagonists with antithrombotic activity. ${ }^{8}$ Several reports mentioned also their therapeutic applications with a wide spectrum of biological activities $^{9}$ as potent antitumoral, antiviral, antibiotics, antifungal agents ${ }^{10}$ and in the central nervous system (CNS) domain for the treatment of several neurological disorders such as epilepsy, Alzheimer's disease, Huntington's disease and amyotrophic lateral sclerosis. ${ }^{11}$ Thus diverse successful therapeutic drugs such as ethoxzolomide, frentizole, riluzole, zopolrestat, and also thioflavin $\mathrm{T}$ as amyloid imaging agent have benzothiazole scaffold. $^{12}$

Jean-Pierre Majoral is Emeritus Director of Research,

Laboratoire Chimie de Coordination, CNRS, 205 route de Narbonne, BP44099, $F$ 31077 Toulouse cedex 4, France. Email: jean-pierre.majoral@Icc-toulouse.fr.

${ }^{b}$. LCC-CNRS, Université de Toulouse, CNRS, Toulouse, France.

c. Department of Pharmacy, Zhengzhou Railway Vocational \& Technical College, Zhengzhou, 450018, China.

d. Centre of Molecular and Macromolecular Studies, Polish Academy of Sciences, Sienkiewicza 112, 90-363, Lodz, Poland.E mail: zabloc@cbmm.lodz.pl.

e. Donghua University, College of Chemistry, Chemical Engineering and

Biotechnology, 2999 North Renmin Road, Songjiang District, Shanghai 201620, P.R. China.

f. Université Paris Descartes, PRES Sorbonne Paris Cité, CNRS UMR 860, Laboratoire de Chimie et de Biochimie Pharmacologiques et Toxicologiques, 45 rue des SaintPères, 75006 Paris, France.

g. CQM-Centro de Quimica da Madeira, MMRG, Universidade da Madeira, Campus da Penteada, 9020-105 Funchal, Portugal.

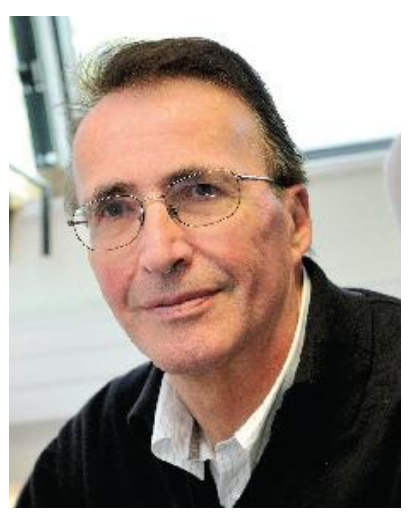

Exceptional Class at the CNRS in Toulouse. His research interest is focused on the design and the properties of macromolecules such as phosphorus dendrimers and hyperbranched polymers. Main efforts are directed at the use of dendrimers in medicinal chemistry, material sciences and catalysis. He is co-founder and scientific director of the start-up Dendris. He is a member of several Academies of Sciences worldwide, got a dozen of international awards, and is an author of over 675 publications, 7 books, 35 book chapters, and 48 patents. ( $h$

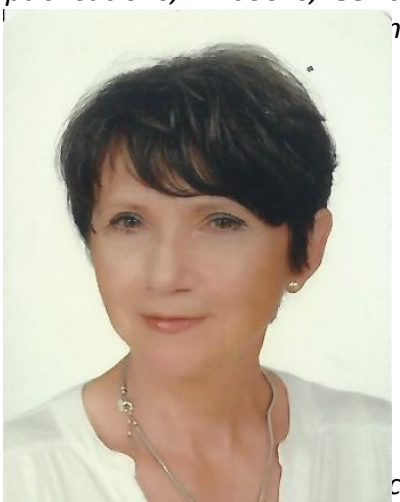
is).

Maria Zablocka received her PhD from the Centre of Molecular and Macromolecular Studies of the Polish Academy of Sciences in Lodz (Poland). Since 1991 as senior researcher and 2013 as adjunct professor, she is strongly involved in different aspects of the design and compounds using monomeric and/or dendritic derivatives in organic and organometallic chemistry as well as in catalysis and in the field of nanomedicine. She authored/co-authored 87 papers, 3book chapters ( $h$ index 24).

The coupling of diverse phosphorus monomers (phosphonate, phosphinate, phosphine etc.) to the backbone of thiazoles or benzothiazoles is a topic of interest, the phosphorus containing moieties being able to increase, to modify their properties or to bring some other possibilities to find new properties and applications not only in medicinal chemistry as mentioned above but also in other fields of research as for 
example coordination or organometallic chemistry and catalysis.

Herein a survey of the preparation of various phosphorus thiazoles and benzothiazoles in which the phosphorus unit is grafted on $\mathrm{C}_{2}, \mathrm{C}_{4}$ or $\mathrm{C}_{5}$ position (Fig. 1 ) onto the thiazole skeleton will be presented as well as some key examples of the formation of various metallocomplexes (Ir, Ru, Pt, Pd, and $\mathrm{Au}(\mathrm{I})$ complexes) and their use in the specific area of catalysis.

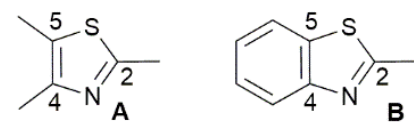

Fig. 1 Chemical structure of thiazole (A) and benzothiazole (B).

\section{Synthesis via $\mathrm{C}_{2}-\mathrm{H}$ phosphonylation of benzo thiazoles and thiazoles}

\section{Synthesis via direct coupling}

The direct $\mathrm{C}_{2}$ phosphonylation of benzothiazoles was performed in the presence of dialkyl phosphonates $\mathrm{HP}(\mathrm{O})(\mathrm{OR})_{2}$ and of a radical initiator as di-tert butyl peroxide DTBP leading to phosphonate substituted benzothiazoles ${ }^{13}$ (Scheme 1, Table 1). Various dialkyl benzothiazol-2-yl phosphonates including those bearing electron-donating and electron-withdrawing groups $\left(\mathrm{CH}_{3}, \mathrm{Br}, \mathrm{Cl}\right.$, and $\left.\mathrm{OCH}_{3}\right)$ (see Table 1 ) were obtained in moderate to good yields (63 to $85 \%$ ).
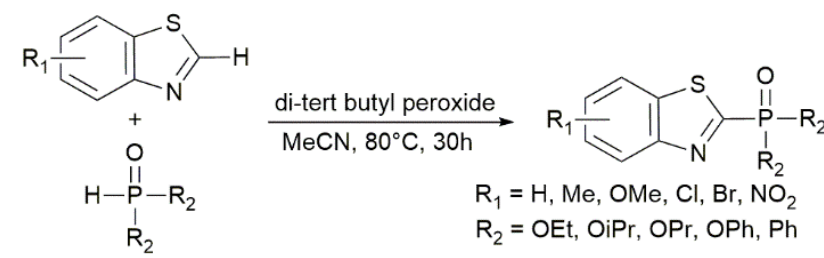

Scheme $1 \quad \mathrm{C}_{2}-\mathrm{H}$ phosphonylation using a radical initiator leading to phosphonate or phosphine oxide.

The direct phosphonylation of thiazoles with dialkyl phosphonates was conducted in the presence of Pd catalysts, 30 mol\% of proline or 2, 2'-bipyridine and 3 equiv. of $\mathrm{K}_{2} \mathrm{~S}_{2} \mathrm{O}_{8}$ as an oxidant and without base or acid (Scheme 2). This process implies the oxidative cleavage of $\mathrm{C}-\mathrm{H}$ and $\mathrm{P}(\mathrm{O})-\mathrm{H}$ bonds and has the advantage to be an atom-efficiency alternative to more classical phosphonylation procedures (Scheme 2). A $\mathrm{Pd}^{\mathrm{II}} / \mathrm{Pd}^{\mathrm{IV}}$ mechanism was postulated by the authors. ${ }^{14}$

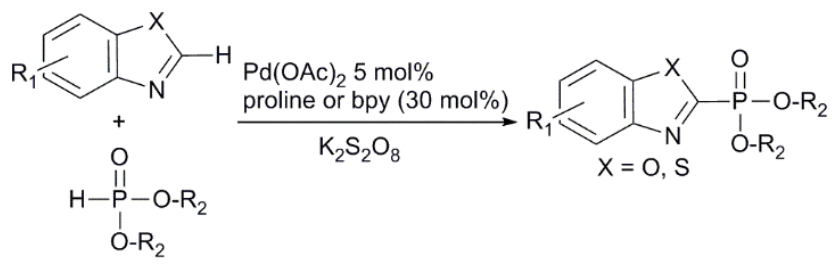

Scheme 2 Phosphonylation of benzothiazoles catalysed by $\operatorname{Pd}(\mathrm{OAc})_{2}$.

The phosphonylation of various benzothiazoles and thiazoles with dialkyl phosphonate in the presence of $\mathrm{AgNO}_{3}$ was also developed. As an example the resulting diphenyl phosphino oxide moiety was reduced in the presence of tetramethyldisiloxane affording the corresponding phosphine derivative which in presence of $\left[\mathrm{Ru}(\text { cymene }) \mathrm{Cl}_{2}\right]_{2}$ led to a neutral P-coordinated ruthenium complex. ${ }^{15}$ The corresponding cationic ruthenium complex in which ruthenium is coordinated both to phosphorus and to the benzothiazole nitrogen atom was formed via the addition of $\mathrm{AgSbF}_{6}$ (Scheme $3)$.

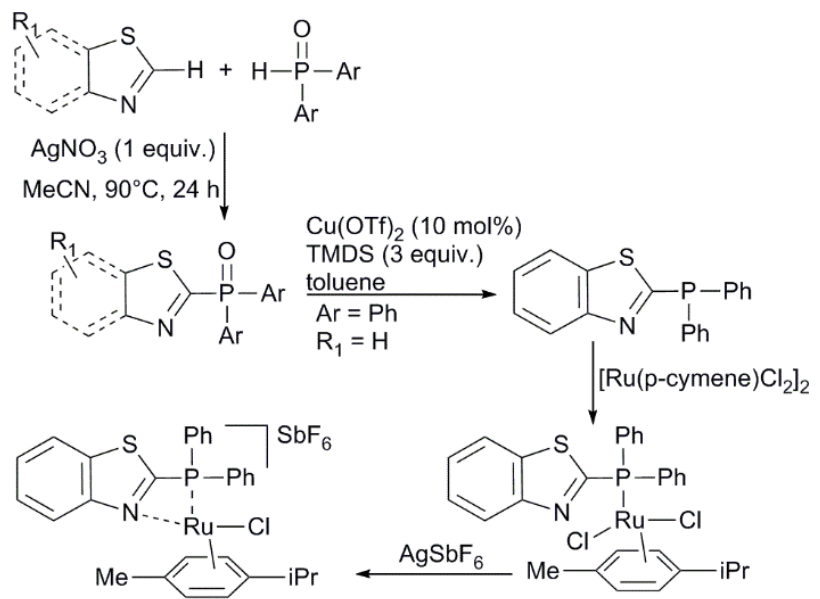

Scheme 3 Synthesis of benzothiazole phosphine Ru(II) complexes.

The use of visible light in the presence of $5 \mathrm{~mol} \%$ eosin B allows also the direct $\mathrm{C}-\mathrm{H}$ phosphonylation of thiazole derivatives with diarylphosphonate. Such a photo-redox process takes place in the absence of any kind of external oxidant, the only by-product of the reaction being molecular hydrogen (Scheme $4 a) .{ }^{16}$

Table 1 Examples of dialkyl benzothiazol-2-yl phosphonates synthesized using a radical initiator synthetic process. 


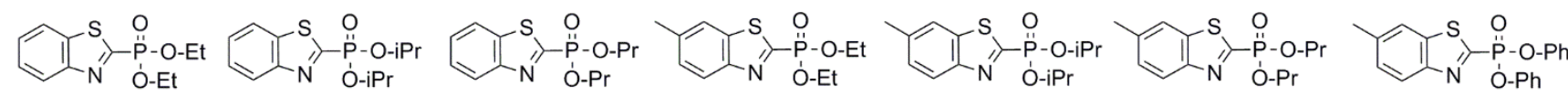

$$
\underbrace{S}_{N}
$$

$$
\text { (N) }
$$

In the same vein, the grafting of various phosphonates to thiazoles was performed in the presence of oxygen under metal-and solvent free conditions (Scheme 4b). It was demonstrated that the reaction implies a radical pathway initiated by the diarylphosphonate. ${ }^{17}$

The first solvent free manganese(III) acetate promoted reaction of benzothiazole derivatives with different phosphorus compounds as phosphine oxides, phosphinate esters, or phosphonate diesters, was also efficiently developed. Using ball-milling conditions, L. Li et al. ${ }^{18}$ prepared in high yield structurally diverse $C_{2}$ phosphonylated benzothiazole/thiazole derivatives (Scheme 4c). More recently, another direct phosphonylation of benzothiazoles and thiazoles was performed using $\mathrm{K}_{2} \mathrm{~S}_{2} \mathrm{O}_{6}$ as the oxidant in moderate yields ${ }^{19}$ (Scheme $4 d$ ).

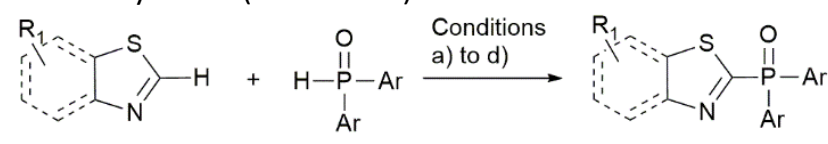

a) Eosin $\mathrm{B}$ (5 mol\%), $\mathrm{CHCl}_{3}, 11 \mathrm{~W}$ LED, $\mathrm{N}_{2}$, rt, $24 \mathrm{~h}$

b) $\mathrm{O}_{2}$ balloon, solvent-free, $65^{\circ} \mathrm{C}, 18 \mathrm{~h}$

c) $\mathrm{Mn}(\mathrm{OAc})_{3}, 2 \mathrm{H}_{2} \mathrm{O}$, ball-milling, under air

d) $\mathrm{K}_{2} \mathrm{~S}_{2} \mathrm{O}_{8}, \mathrm{MeCN}$ (or dioxane), $70^{\circ} \mathrm{C}$

Scheme 4 Different ways of phosphonylation of thiazoles and benzothiazoles.

All these experiments led to the formation of phosphonate substituted thiazolyl derivatives but did not afford directly the corresponding phosphine derivatives, which were reported only in two cases, the first one involving the reduction of the corresponding phosphine oxide ${ }^{15}$ (Scheme 3). In another report a benzothiazole phosphine 1 and tris(thiazole) phosphine 2, have been prepared by reaction of the corresponding heteroaryl organolithium reagent, then addition of chlorotrimethylsilane followed by electrophilic cleavage of the resulting 2-(trimethylsilyl) substituted heteroaromatic compound with $\mathrm{PCl}_{3}{ }^{20}$ They react readily with $[1,5$ cyclooctadiene dimethyl platinum(II)] affording the cisdimethyl bis (phosphine) platinum(II) complexes 3a, 3b (Scheme 5).

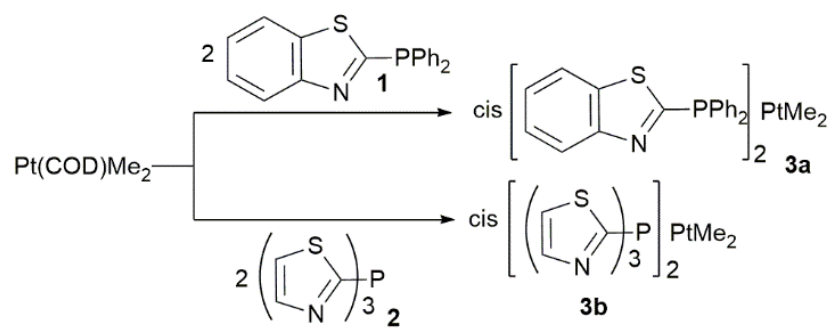

Scheme 5 Synthesis of heteroaromatic phosphines and their corresponding Pt complexes.

The tris (thiazoyl) phosphines $\mathbf{4 a - b}$ and $\mathbf{2}$ react with $\mathrm{Au}(\mathrm{I})$ (tht) to give the expected gold complexes $\mathbf{5 a - c}$. Substitution of the chloride in $\mathbf{5 a}$ leads to the two complexes $\mathbf{6 a}$ and $\mathbf{7 a}$ by using aqueous NaNCS in a biphasic reaction or by treatment with RSLi ( $\mathrm{R}=\mathrm{CH}_{2} \mathrm{C}_{6} \mathrm{H}_{5}, \mathrm{C}_{6} \mathrm{H}_{5}$ or $\mathrm{C}_{6} \mathrm{H}_{5} \mathrm{CO}$ ) in anhydrous $\mathrm{THF}^{21,22}$ (Scheme 6).

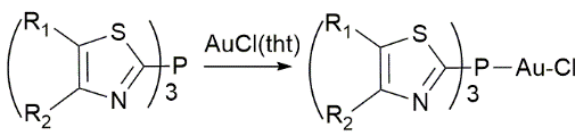

$$
\begin{aligned}
& \begin{array}{ll|l}
\text { 4a } \mathrm{R}_{1}=\mathrm{H}, \mathrm{R}_{2}=\mathrm{Me} \longrightarrow 5 \mathrm{a} & \\
\text { 4b } \mathrm{R}_{1}=\mathrm{R}_{2}=\mathrm{Me} \longrightarrow 5 \mathrm{~b} & \mathrm{R}_{1}=\mathrm{H}, \mathrm{R}_{2}=\mathrm{Me} \\
2 \mathrm{R}_{1}=\mathrm{R}_{2}=\mathrm{H} \longrightarrow 5 \mathrm{c} &
\end{array}
\end{aligned}
$$

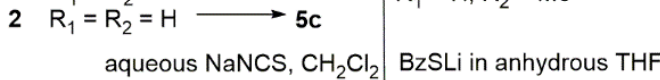

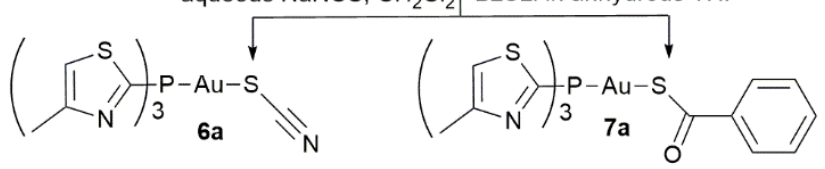

Scheme $6 \mathrm{Au}(\mathrm{I})$ complexes of phosphines substituted by three thiazole units.

\section{$\mathrm{C}_{2}-\mathrm{P}$ coupling via a linker}

Introduction of different phosphorus derivatives via a linker to thiazoles in the $C_{2}$ position can be easily performed via addition of silylated phosphorus esters to aldimines. Further treatment of the silylated derivatives with methanol affords the expected thiazole aminophosphonic acids $\mathbf{8} \mathbf{a}, \mathbf{b}$ in good yields which were found effective ligands for complexation of $\mathrm{Cu}(\mathrm{II})^{23,24}$ (Scheme 7). The use of silylated phosphoesters obtained from ethyl phenyl phosphinate and bromotrimethylsilane led to the formation of the corresponding aminophosphonic acids 9a,b (Scheme 7). Similarly the analogous derivative bearing diphenyl phosphine oxide grafted to thiazole gives rise to the aminophosphonates $10 \mathbf{a}, \mathbf{b}$ also in good yield, using the same methodology. 


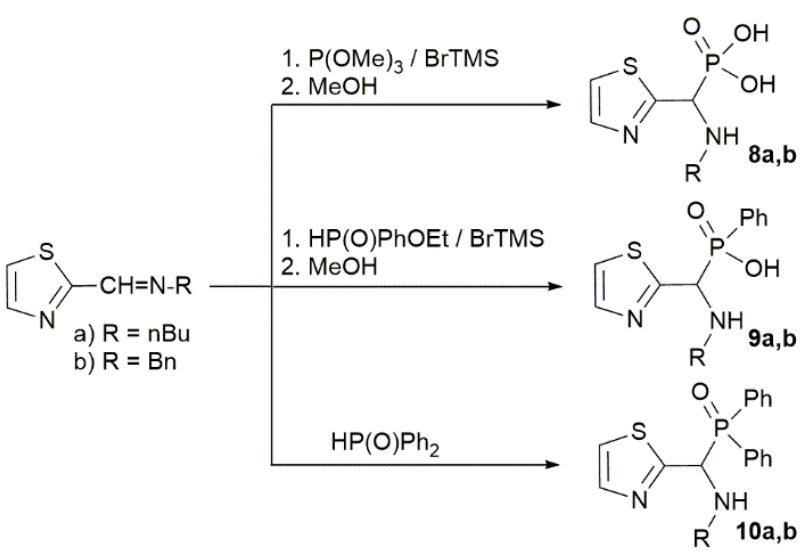

Scheme 7 Preparation of thiazole-2-yl(amino)methylphosphonic, phosphinic acids and aminophosphine oxides $\mathbf{8 a , b - 1 0 a , b}$.

Bicyclic phosphine-thiazole ligands were prepared from Boc protected thioamide which was reacted with alpha bromoketone to afford the thiazoles $\mathbf{1 1}$ then the amines $\mathbf{1 2}$ which further were submitted to react with a diarylphosphine chloride in the presence of DIPEA to give the aminophosphine 13. Complexation of $\mathbf{1 3}$ with $[\operatorname{Ir}(\mathrm{COD}) \mathrm{Cl}]_{2}$ followed by counterion exchange with $\mathrm{NaBAr}_{\mathrm{F}}$ affords the complex $14^{25}$ (Scheme 8).

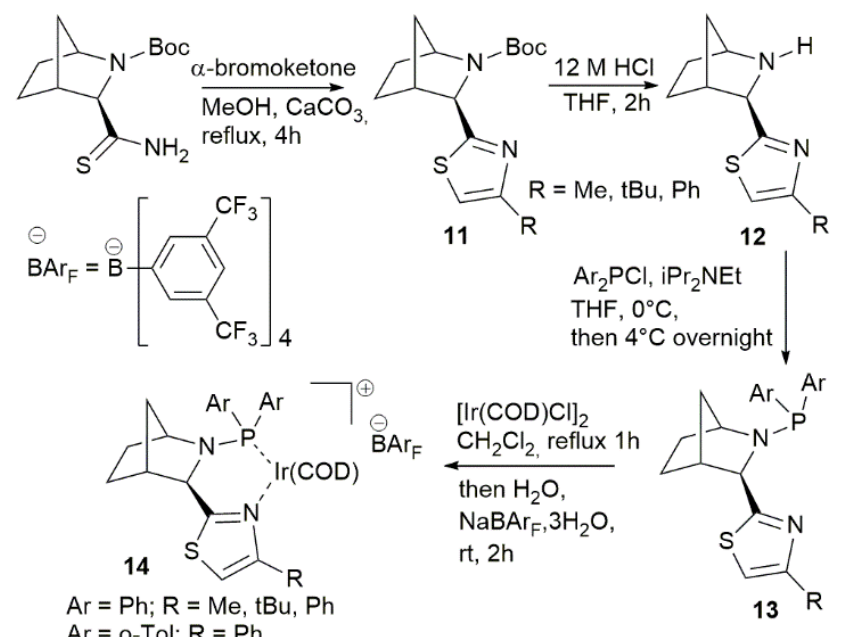

Scheme 8 Synthesis of bicyclic thiazole phosphines and their $\mathrm{Ir}$ complexes.

Recently P.G. Andersson, M. Dieguez et al. reported also the synthesis of thiazole phosphine derivatives 15 (R) and (S) bearing a $\pi$-acceptor biaryl phosphoroamidite Their complexation with $[\operatorname{Ir}(\mathrm{COD}) \mathrm{Cl}]_{2}$ leads to the corresponding $\mathrm{Ir}$ complexes $16^{26}$ (Scheme 9).

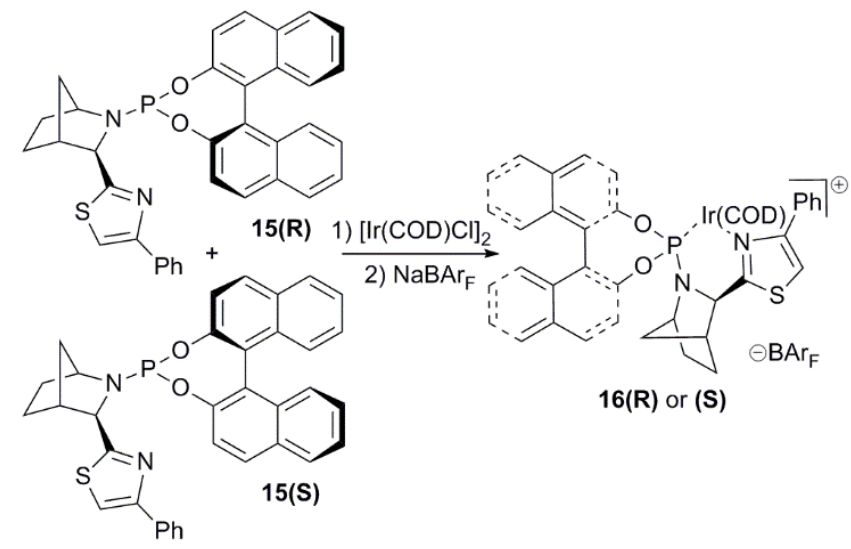

Scheme 9 Biaryl phosphoramidite substituted thiazoles 15(R) and 15(S) and related Ir complexes 16.

2-bromothiazole reacts with $\mathrm{Pd}\left(\mathrm{PPh}_{3}\right)_{4}$ at $-20^{\circ} \mathrm{C}$ to give the palladium complex 17 slowly converted to the dipalladium complex 18, each palladium being connected to two thiazole units, one at the $\mathrm{C}_{2}$ position and the other one at the nitrogen atom of the thiazole ring $^{27}$ (Scheme 10). These complexes were fully characterized by X-ray diffraction analysis.

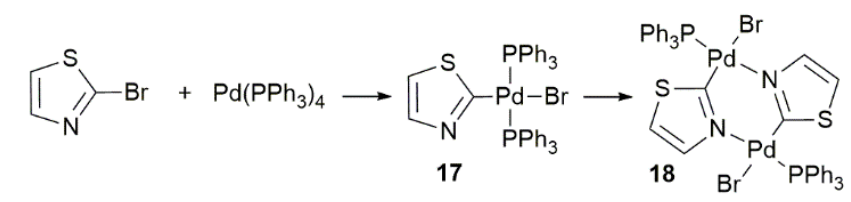

Scheme 10 Synthesis of a dipalladium phosphorus complex of thiazole.

\section{Catalytic properties}

Highly active and enantioselective asymmetric hydrogenations of several olefins were performed using the iridium complexes $14(\mathrm{Ar}=\mathrm{Ph}, \mathrm{R}=\mathrm{Ph}$, Scheme 8$)($ Scheme 11$),{ }^{28}$ as well as the first Ir-catalysed asymmetric hydrogenation of vinyl boronates with good selectivities (76-98\% ee) using low catalyst loading (0.5 mol\%) and pressure with good selectivities (76-98\% ee). ${ }^{29}$ Access to chiral tertiary amines via the iridium-catalysed asymmetric hydrogenation of enamines was also investigated. ${ }^{30}$

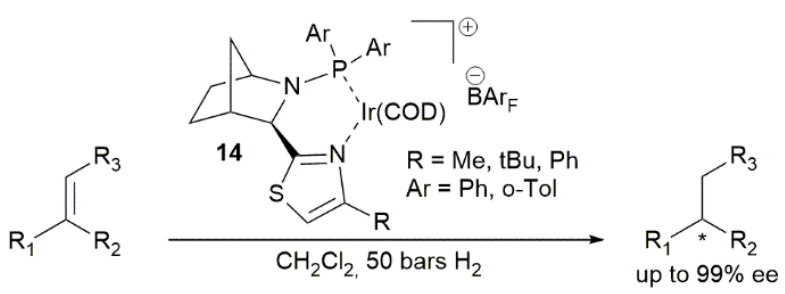

Scheme 11 Example of hydrogenation of olefins with the Ir complex 14 .

Ir-bicyclic phosphoroamidite-thiazole complexes 16(R), 16(S) (Scheme 9) were used as catalytic systems able to hydrogenate a range of minimally functionalized olefins as E- and Z-tri-and disubstituted substrates as well as enol phosphinates, vinylsilanes, alkenyl boronic esters in high enantioselectivities 
(ee values up to 99\%) (Scheme 11). Indeed the simple substitution of the $N$ phosphine unit in 14 by a phosphoramidite group allows to extend the range of olefins which could be hydrogenated with high enantioselectivity. This route appears to be more efficient, straightforward, sustainable and selective than alternative methods. ${ }^{26}$

\section{$\mathrm{C}_{4}$ and $\mathrm{C}_{4-5}$ phosphonylation of thiazoles via a linker}

\section{Synthesis and complexation}

All these reported $\mathrm{C}-\mathrm{H}$ phosphonylations shown above take place on the $\mathrm{Csp}_{2}$ carbon of the $\mathrm{S}-\mathrm{CH}-\mathrm{N}=$ fragment that is to say in position 2 of the thiazole unit. There is no example of a direct $C_{4}$ substitution with phosphorus units $\left(C_{4}-P\right.$ bond). In contrast several $\mathrm{C}_{4}$ substitutions via a linker are reported.

The thiazole amino phosphonate and phosphinates 19-21 were prepared in good yield using a protocol analogue to the one reported in Scheme 7 but starting from thiazole 4-imine. These derivatives are stable under acidic conditions in marked contrast with the analogous thiazole 2 -amino phosphonates ${ }^{23}$ (Fig. 2).

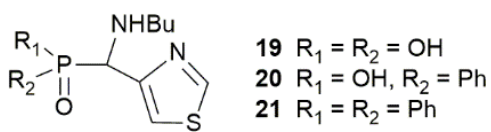

Fig. 2 Structures of thiazole phosphonate and phosphinates 19-21.

Phosphonate-containing ketones 22, 23 shown in Scheme 12 were readily converted to aminothiazoles using copper (II) bromide. Cyclisation reactions with thiourea gave aminothiazoles $\mathbf{2 4}$ whereas cyclisation with thioamides gave other $C_{4}$ substituted thiazole derivatives 25 (Scheme 12). Analogous $\mathrm{C}_{4}$ thiazole analogues of $\mathbf{2 5}$ were also readily prepared from compounds $\mathbf{2 4}$ through Sandmeyer reactions (Scheme 12). Indeed direct conversion of the 2-amino group to a 2-chloro group was accomplished by treatment of thiazole $\mathbf{2 4}$ with isoamyl nitrite in the presence of copper(II) chloride producing thiazole $25(\mathrm{R}=\mathrm{Cl})$. Alternatively, reactions of thiazole 24 with isoamyl nitrite and copper (II) bromide or (methylthio)trimethylsilane gave thiazoles $\mathbf{2 5}(\mathrm{R}=\mathrm{Br})$ and $\mathbf{2 5}(\mathrm{R}$ $=\mathrm{SMe}$ ) respectively (Scheme 12$).{ }^{31}$

Several other $\mathrm{C}_{4}$ substituted analogues $\mathbf{2 6}$ were also reported by the same authors and finally a large number of thiazole phosphinic acids $\mathbf{2 7}$ were readily obtained via trimethylsily bromide-mediated removal of phosphonate diethyl esters from thiazoles 26 (Scheme 12). Some of these phosphonic acid-containing thiazoles exhibited high $\mathrm{IC}_{50}(10-30 \mathrm{nM})$ against human liver FBPase as well as a high selectivity relative to other 5 '-adenosine monophosphate (AMP)-binding enzymes. Remarkably compound $\mathbf{2 8}$, was found to be the first oral FBPase inhibitor advancing to human chemical trials as a potential treatment of type 2 diabetes mellitus (T2DM).
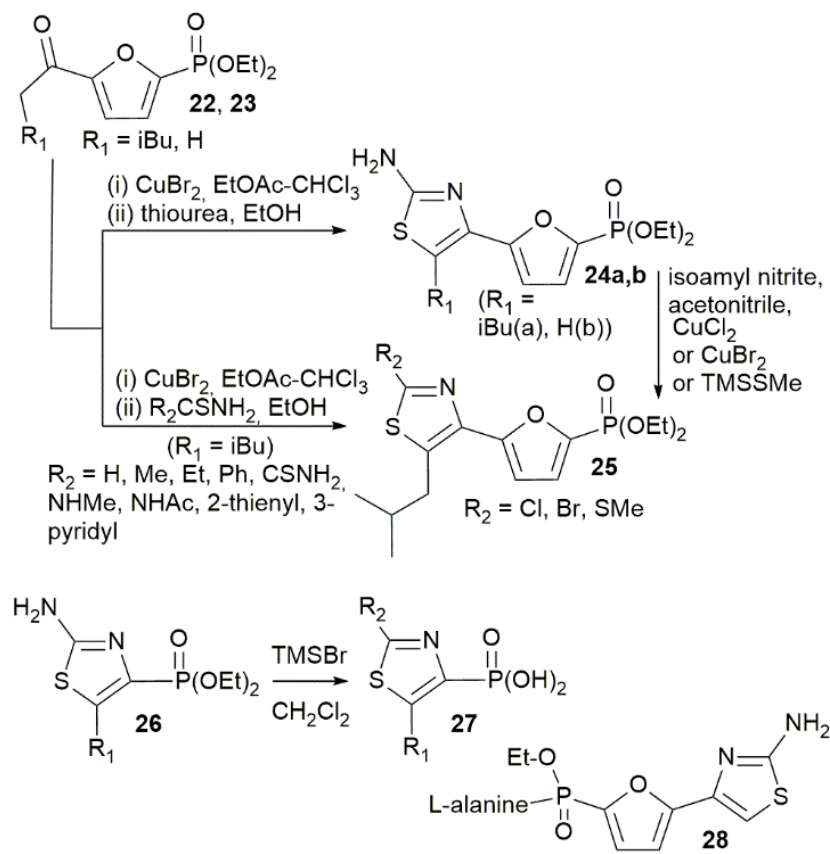

Scheme 12 Synthetic pathways for the preparation of thiazoles substituted via a linker to phosphonates or phosphinic groups.

The team of P.G. Andersson has nicely prepared a variety of $C_{4}$ and $\mathrm{C}_{4}-\mathrm{C}_{5}$ substituted thiazole phosphines 29 and $\mathbf{3 1}$ via multistep procedures as well as their corresponding Ir complexes $\mathbf{3 0}$ and $\mathbf{3 2}$ as shown in Schemes 13 and $14 .^{32,33}$

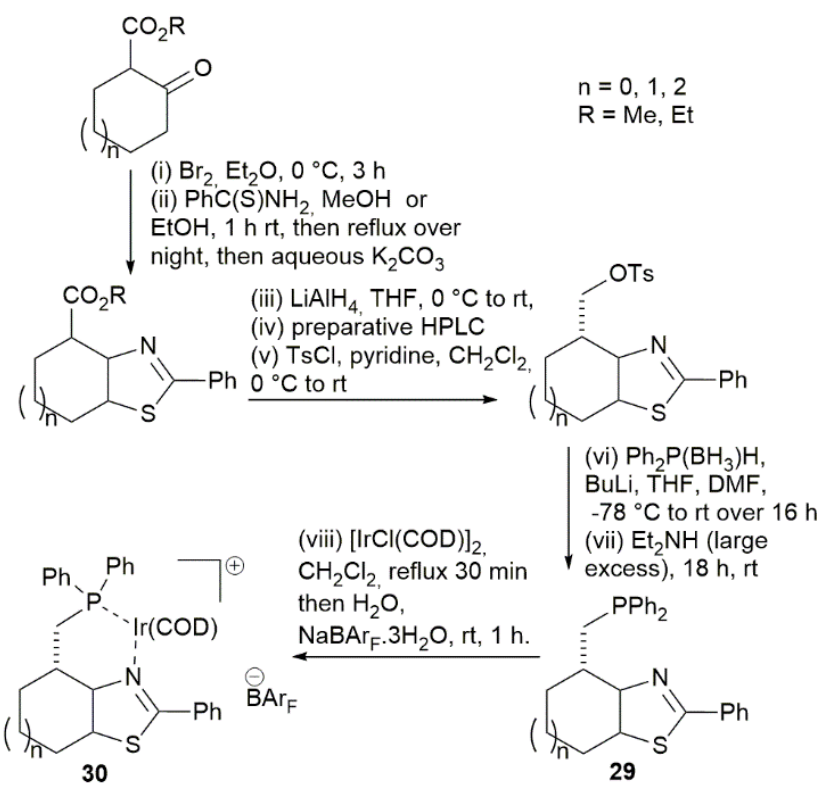

Scheme 13 Synthesis of the thiazole phosphines 29 and the Ir complex 30 


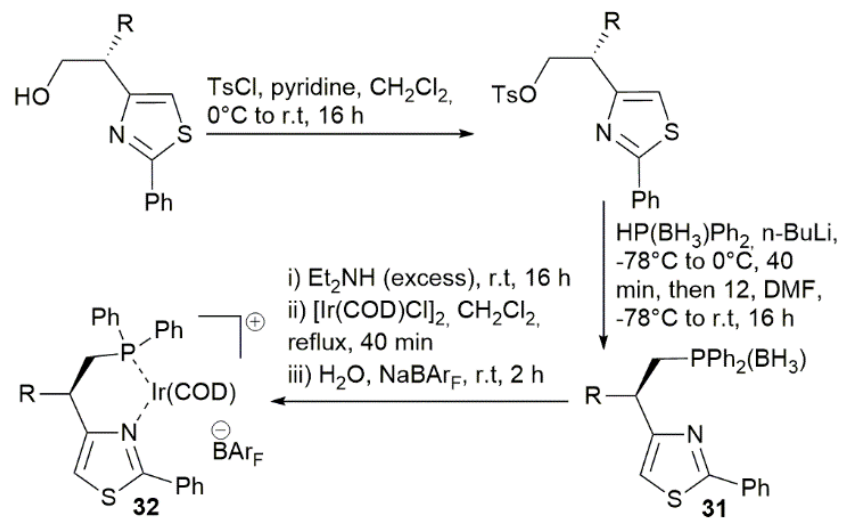

Scheme 14 Synthesis of the thiazole protected phosphine $\mathbf{3 1}$ and the Ir complex $\mathbf{3 2}$.

\section{Catalytic properties}

The use of various thiazole phosphines in catalysis was exemplified by the Andersson team. Iridium phosphine thiazole complexes differing from the size of the ring (five, six or seven membered ring) connected in position 4-5 of the thiazole unit were used for the asymmetric hydrogenation of aryl alkenes and aryl alkene esters (Fig. 3). It was demonstrated that the size of the ring has a major influence on the stereochemical outcome of the final products, the best results being obtained with the Ir complex bearing a sixmembered ring. Interestingly even with typically difficult substrates, good to excellent enantioselectivity can be observed. $^{30}$
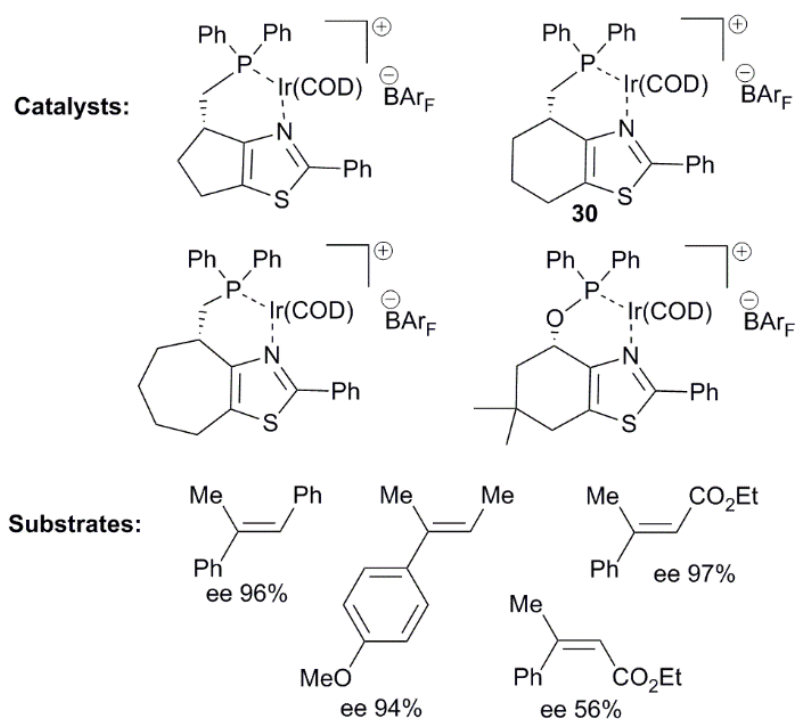

Fig. 3 Bicyclic thiazole phosphine Ir-complexes used as catalysts in asymmetric hydrogenation of the substrates. Examples of ee values obtained using complex $\mathbf{3 0}$.

Other thiazole-based chiral N-P ligands as the ones shown in Scheme 14 bearing open chain analogues of thiazole ligands were also used in the iridium-catalysed asymmetric hydrogenation of trisubstituted olefins. Indeed the chirality was introduced at the level of the ligand via a highly diastereoselective alkylation using Oppolzer's camphorsultam. The potency of the resulting Ir catalysts compared well with that found for the cyclic analogues. ${ }^{33}$

Microwave heating of some of these thiazole phosphines (Fig. 4) in the presence of $1.5 \mathrm{~mol} \% \mathrm{Pd}_{2}(\mathrm{dba})_{3}$ catalysed asymmetric intermolecular Heck coupling of 2, 3-dihydrofuran with some triflates as aryl triflates and cyclohexenyl triflate with complete conversion in a few hours and excellent enantioselectivities. ${ }^{32}$

$$
\begin{array}{ll}
\mathrm{R}=\mathrm{Ph} ; \mathrm{Ar}=\mathrm{Ph}(R) \\
\mathrm{R}=\mathrm{Ph} ; \mathrm{Ar}=0-\mathrm{Tol}(R) \\
\mathrm{R}=\mathrm{H} ; \mathrm{Ar}=\mathrm{o}-\mathrm{Tol}(\mathrm{S}) \\
\mathrm{R}=\mathrm{Ph} ; \mathrm{Ar}=3,5 \text {-dimethylphenyl }(R) \\
\mathrm{R}=3,5-\operatorname{dimethylphenyl;} \mathrm{Ar}=\mathrm{o}-\mathrm{Tol}(\mathrm{S}) \\
\mathrm{R}=\mathrm{Mesityl} ; \mathrm{Ar}=\mathrm{Ph}(\mathrm{S})
\end{array}
$$

Fig. 4 Thiazole phosphine ligands for Pd catalysed intermolecular Heck coupling of 2,3 dihydrofuran.

\section{Thiazole phosphines via $\mathrm{C}_{5}$ substitution}

\section{Synthesis}

G.V. Oshovsky et al. developed an elegant way for the preparation of phosphonylated thiazole $\mathbf{3 3}$ via $\mathrm{C}_{5}$-substitution of 2-thiazoylformamidine with phosphorus tribromide, the 1,3diazabut-1-enyl formamidine substituent being used both as an activating and a protective group ${ }^{34-36}$ (Scheme 15).

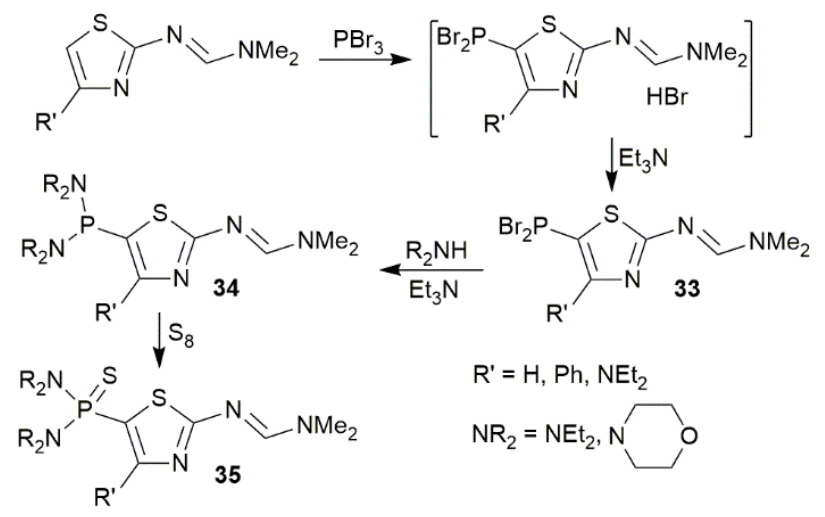

Scheme 15 Synthesis of thiazole substituted formamidine phosphines.

Reaction of thiazole dibromo phosphines with secondary amines yield the corresponding thiazole diaminophosphines $\mathbf{3 4}$ which further react with sulfur to give the corresponding thiophosphonates 35. Similarly such a methodology allows to prepare bis and tris thiazoyl formamidine phosphines 36a-c: the formamide group can be easily removed by hydrolysis to afford the amino thiazole 5-phosphonylated-derivatives 37a-c (Scheme 16).

A methanolic solution of $37 \mathrm{a}-\mathrm{c}$ treated with an excess of aqueous hydrochloric acid under mild conditions gave rise to the salts 38a-c, the protonation taking place on the more basic imino nitrogen atom. The water solubility of these salts depends of the number of thiazolium units linked to the phosphorus atom. Indeed the salt 38a (only a thiazolium unit) 
is soluble in water up to $6 \mathrm{~g} / \mathrm{L}$, while the presence of two or three thiazolium moieties results in an increase of solubility in water: $250 \mathrm{~g} / \mathrm{L}$ for $\mathbf{3 8 b}, 275 \mathrm{~g} / \mathrm{L}$ for $\mathbf{3 8 c}$. Similarly, mild hydrolysis of the formamidine counterpart of thiazoyl-thio- or oxo- phosphines affords the expected amino derivatives 39a$c^{34-36}$ (Scheme 16).

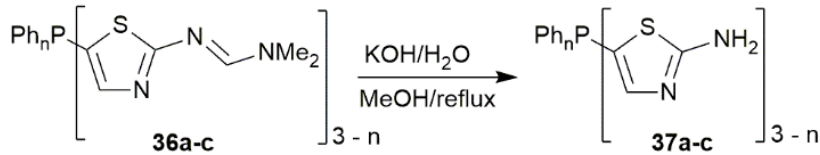

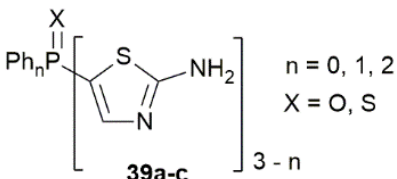

$$
\begin{aligned}
& ]_{3-\mathrm{n}}
\end{aligned}
$$

Scheme 16 Synthesis of water-soluble thiazole phosphines.

The phosphino group in these thiazole phosphines easily react with azidodiphenoxyphosphine oxide or sulfide leading via a Staudinger type reaction to the quantitative formation of the thiazole iminophosphoranes ${ }^{37-39}$ as exemplified in Scheme 17.

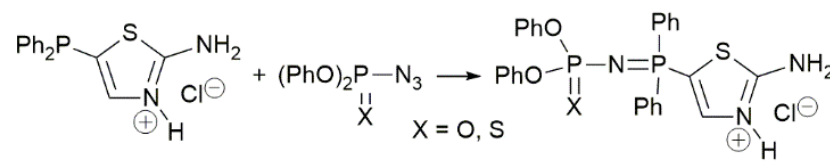

Scheme 17 Thiazole substituted iminophosphoranes.

$\mathrm{Au}(\mathrm{I})$ complexation of these thiazole phosphines leads respectively to two different complexes: the expected gold complexes where one thiazole phosphine ligand is connected to $\mathrm{Au}(\mathrm{I}) \mathrm{Cl}$ (complexes 40, 42) and another one where three tristhiazole phosphino groups are connected to $A u(I) \quad 41$ (Scheme 18). Structures were corroborated by NMR, mass spectrometry as well as by X-Ray diffraction studies. ${ }^{39}$

$$
\longrightarrow
$$

Scheme $18 A u(I)$ complexes of mono or tris substituted thiazole phosphines $\mathbf{4 0 - 4 2}$.

Interestingly treatment of $\mathbf{4 3}$ with bromoacetone leads to via heterocyclisation to the 2-phosphorylated imidazo [2,1thiazole] $44^{35}$ (Scheme 19).

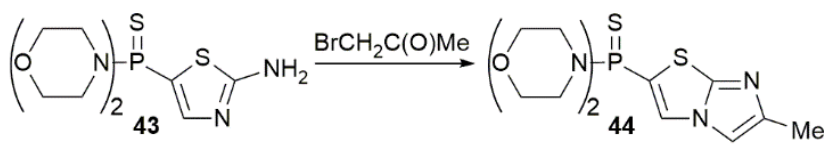

Scheme 19 Synthesis of imidazo thiazole thiophosphine 44.

Later on, Sinou et al. proposed the synthesis of di-substituted thiazole phosphines via the reaction of dialkylamino thiazoles with $\mathrm{Ph}_{2} \mathrm{PBr}$. Saponification of the resulting thiazoles gave the heterocyclic carboxylic phosphines $45 \mathrm{a}, \mathbf{b}$ in 70 to $73 \%$ yield (Scheme 20). ${ }^{40}$

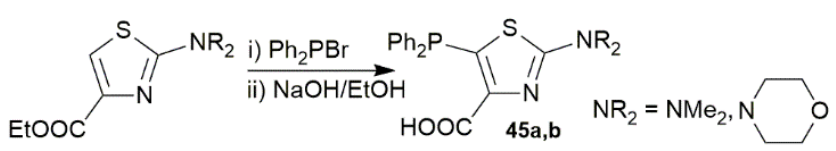

Scheme 20 Thiazole substituted in $\mathrm{C}_{4}$ position with carboxylic group and in $C_{5}$ with diphenyl phosphine.

$[1,3,4]$-thiadiazole phosphines represent a class of practically unknown compounds. Indeed only two derivatives are reported: the $\mathrm{N}, \mathrm{N}$-dimethyl $\mathrm{N}$-(5-(2-(1,3-diaza-but-1-enyl) thiazole phosphine 47 and the $\mathrm{N}, \mathrm{N}$-dimethyl $\mathrm{N}$-(5-(2aminothiadiazole)) phosphine 48 . obtained from the reaction of the imine $\mathbf{4 6}$ and chlorodiphenyl phosphine. Their synthesis is shown in Scheme 21. The P-C bond between the trivalent phosphorus atom and the $C_{5}$ thiadiazoyl endocyclic carbon atom is stable in the presence of bases, but can be easily cleaved by acids. The stability in basic media is demonstrated by the synthesis of the aminothiadiazole phosphine $\mathbf{4 8}$ from the corresponding amidine $\mathbf{4 7}$ by treatment with potassium hydroxide in aqueous methanol. However attempts to prepare water-soluble salts of the aminothiadiazole phosphine $\mathbf{4 8}$ led to the cleavage of the P-C bond, in contrast with what is observed with the analogous aminothiazole phosphines $37 a, c^{39}$

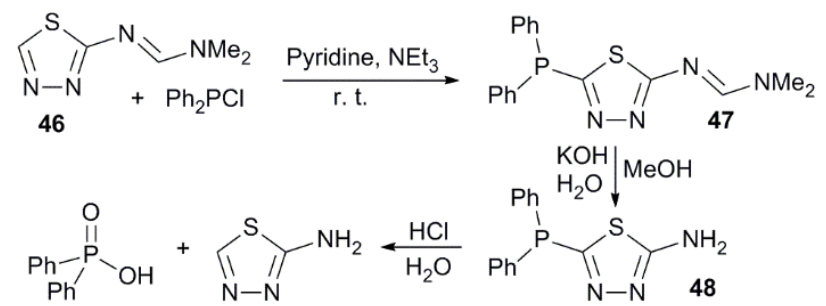

Scheme 21 Synthesis of thiadiazole phosphines.

The thiadiazole phosphine 47 easily reacts with $\mathrm{RuCl}_{2}(\mathrm{p}-$ cymene)-dimer in dichloromethane to form the complex $49^{36}$ (Fig. 5).

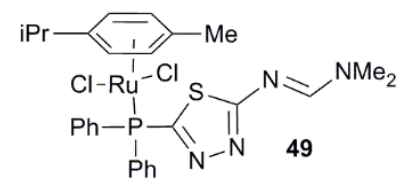

Fig. 5 Ru complex of the thiadiazole phosphine 49. 


\section{Catalytic properties of $C_{5}$ substituted thiazoyl phosphines and their complexes}

The arylation of pyrazole with bromobenzene was investigated in the presence of Cul and thiazoyl phosphines 36a-c or amino thiazoyl phosphines 37a-c. It clearly appeared that the monosubstituted ligands $\mathbf{3 6} \mathbf{a}$ and $\mathbf{3 7 a}$ are more efficient than the corresponding di or trisubstituted ones $36 \mathrm{~b}, \mathbf{3 7 b}$ and $36 \mathrm{c}$, 37c: full conversion into phenyl pyrazole was observed with $36 \mathrm{a}$ and $37 \mathrm{a}$ at $80^{\circ} \mathrm{C}$ in $15 \mathrm{~h}$. versus $70 \%$ for the others. ${ }^{41}$ No marked differences are observed between 36a and 37a or between 36b and 37b or 36c and 37c meaning that the formamidine moiety does not play an essential role during the catalytic process. Interestingly a cooperative effect was observed between the phosphine moiety and the thiazoyl unit in 36a and 37a because the same experiments conducted with either the thiazole $\mathbf{5 0}$ instead of the thiazoyl phosphines on one hand or with triphenylphosphine alone led to poor yield of phenylpyrazole. It was claimed that the phosphine could stabilize copper in a lower oxidation state thank to its $\pi$ character, while the nitrogen $\sigma$-donor could facilitate oxidative addition. The thiazoyl phosphine 37a was also found to be the most efficient ligand for similar experiments but using a variety of aryl bromide bearing either electron withdrawing substituents as $\mathrm{CN}, \mathrm{NO}_{2}, \mathrm{Ph}$ and $\mathrm{C}(\mathrm{O}) \mathrm{Me}$, or electron donating (Me, OMe) substituents.

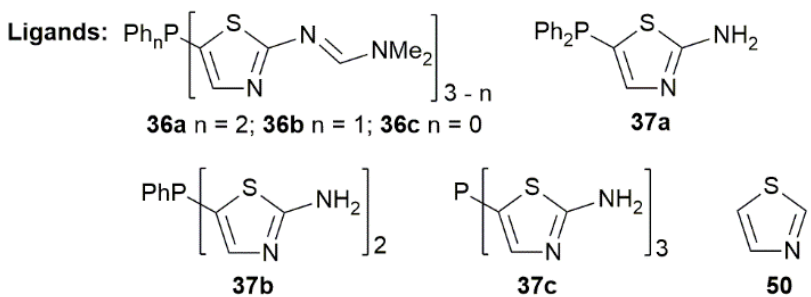

Catalyzed reactions:

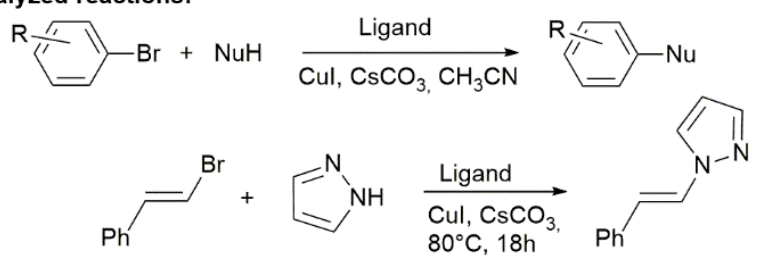

Scheme 22 Thiazole phosphines used for arylation of nucleophiles and vinylation of pyrazole.

These investigations were successfully extended to vinylation by $\beta$-bromostyrene: quantitative yield of styrylpyrazole is obtained at room temperature after 3 days, as well as to the arylation of heterocycles such as pyrrole and indole.

All these experiments were conducted in an organic solvent as acetonitrile but interestingly some of them can be performed in mixed aqueous / organic solvents as well as in a few cases in pure water. Phenyl bromide and $\beta$-bromostyrene are converted in very high to quantitative yields under mild conditions when the catalytic process is performed in a $\mathrm{CH}_{3} \mathrm{CN} / \mathrm{H}_{2} \mathrm{O}(4 / 1)$ solution using the thiazole phosphine 37a. Due to the low solubility of the different reactants, yields dramatically decrease when the reaction is done in pure water
Addition of hexadecyltriethylammonium bromide as phase transfer catalyst allows to slightly increase the yield (65\% for example from $\beta$-bromostyrene). ${ }^{41}$

Hydrophilic phosphine ligands as for example the phosphoadamantane (PTA 1,3,5-triaza-7phosphoadamantane $)^{42}$ or the trihydrazino phosphoadamantane (THPTA 2,4,10-trimethyl-1,2,4,5,7,10hexaaza-3-phosphoadamantane $)^{43,44}$ (Fig. 6) and their ruthenium complexes were found very attractive for a variety of catalytic procedures. In the case of nitrile hydration, the key nucleophilic attack by water on the coordinated nitrile is favoured.
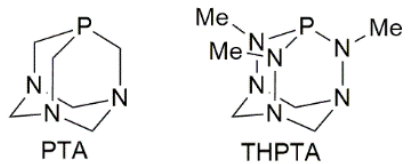

Fig. 6 Structure of the phosphoadamantane (PTA) and of the trihydrazino phosphoadamantane (THPTA).

In the case of the thiazoyl phosphines 38a-c, the treatment of their hydrochloride salts with ruthenium (II) dimer $[\mathrm{RuCl}(\mu$ $\mathrm{Cl})\left(n^{6}\right.$-p-cymene $\left.)\right]_{2}$ in methanol or water affords the mononuclear complexes 51a-c which are significantly soluble in water $\left(<1 \mathrm{gL}^{-1}\right.$ for $51 \mathrm{a}, 7 \mathrm{gL}^{-1}$ for $51 \mathrm{~b}$ and $8 \mathrm{gL}^{-1}$ for $\left.51 \mathrm{c}\right)$ (Scheme 23). All these complexes were found to be active catalysts for the hydration of nitriles to primary amides, providing for example benzamide from benzonitrile, ${ }^{45}$ the best results being obtained with the complex 51c that incorporated three thiazole groups (yield $>99 \%$ at $100^{\circ} \mathrm{C}, 95 \%$ at $40^{\circ} \mathrm{C}$ for $48 \mathrm{~h})$. Such a result was tentatively explained by the growing number of hydrogen acceptor groups i.e. sulphur atoms and $\mathrm{NH}_{2}$ able to activate the nucleophilic water. Remarkably the complex $\mathbf{5 1 c}$ is highly active in a wide range of temperatures. Hydration of a variety of functionalized benzonitriles, heteroaromatic benzonitriles, and chloroacetonitrile was successfully investigated leading to the corresponding benzamides in high yields.

Among the other fascinating catalytic properties of the ruthenium complexes, it can be emphasized the rearrangement of selected aromatic, heteroaromatic, aliphatic and $\alpha, \beta$-unsaturated aldoximes affording the desired primary amides in $>90 \% \mathrm{GC}$ yield after $7 \mathrm{~h}$. of heating at $100^{\circ} \mathrm{C}$. Moreover the reaction of aldehydes with hydroxylamine hydrochloride in the presence of complex 51c and a base as $\mathrm{NaHCO}_{3}$ give rise in a one pot synthesis to the same primary amide. $^{45}$ 


$$
\text { (38a n=2 }
$$

Scheme 23 Thiazole phosphine Ru complexes for the one pot synthesis of primary amides from aldehydes.

Through all these experiments it appears that the watersoluble tris thiazoyl phosphine Ru complex 51c is a better catalyst than the corresponding PTA or $\mathrm{P}\left(\mathrm{NMe}_{2}\right)_{3} \mathrm{Ru}$ complexes for a number of reactions.

Sinou et al. ${ }^{40}$ reported the palladium catalysed cross-coupling reactions of several aryl iodides and bromides and boronic acids in the presence of a very low amount of stable carbohydrate-based thiazole phosphines $\mathbf{5 2 a}$ or $\mathbf{5 2 b}$ (Fig. 7). The polyhydroxylated ligand $\mathbf{5 2 a}$ gave more active catalysts than the peracetylated ligand $\mathbf{5 2} \mathbf{b}$.

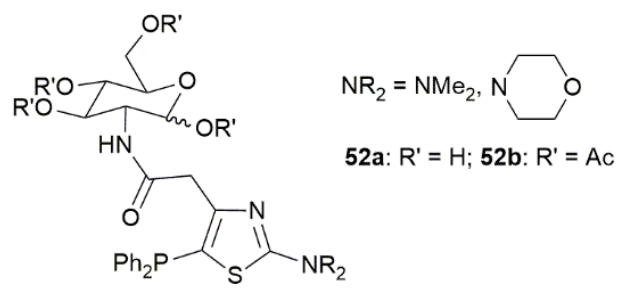

Fig. 7 Thiazole phosphines used in the palladium catalysed cross-coupling reaction of aryl halides with aryl boronic acids.

It is well known that Suzuki coupling reactions can also be performed on a variety of supports. ${ }^{46}$ Among these supports, dendrimers were found very efficient to immobilize numerous catalysts able to promote a variety of reactions. ${ }^{47-49}$ As an example, a strong positive dendritic effect could be observed in copper-catalysed arylations of nucleophiles when using nitrogen ligands supported on dendrimers. ${ }^{50}$ Suzuki couplings can be performed in organic media, ${ }^{51-53}$ some others in aqueous media, ${ }^{54-56}$ and several methods were used to recycle them: nanofiltration, ${ }^{54}$ dialysis, ${ }^{55}$ or precipitation. ${ }^{52}$

The contribution of the thiazole phosphines grafted on the surface of phosphorus dendrimers $\mathbf{G}_{\mathbf{1}}$ thia (dendrimer of generation 1 bearing 12 terminal thiazole phosphine units), and $\mathbf{G}_{3}$ thia (dendrimer of generation 3 bearing 48 terminal thiazole phosphine units) was evaluated in Suzuki reactions in the presence of $\mathrm{Pd}(\mathrm{OAc})_{2}$ and compared with that of the same type of phosphorus dendrimers incorporating triphenylphosphine ligands on their outer shell $\left(\mathbf{G}_{\mathbf{1}} \mathbf{P} \mathbf{P \mathbf { h } _ { 2 }}\right.$ and $\mathbf{G}_{3} \mathbf{P P h} \mathbf{h}_{\mathbf{2}}$ respectively) or with the monomeric thiazole phosphine 53b and triphenyl phosphine itself. It was found that $\mathbf{5 3 b}$ is much more efficient than triphenyl phosphine itself or than the thiazole 54, strongly suggesting the existence of a synergetic effect between the diphenyl phosphorus moiety and the thiazole ring ${ }^{57}$ (Scheme 24).

Interestingly the use of phosphorus dendrimers $\mathbf{G}_{1}$ thia and $\mathbf{G}_{3}$ thia allows the reactions to be performed under mild conditions in water-THF mixtures and to perform the reactions at least 4 times without loss of activity ${ }^{57}$ (Table 2 entry 7.07.4), in marked contrast with what was observed with the triphenylphosphine dendritic species (Table 2, entry 8.0-8.4); in this case remarkably the palladium leaching was found to be

\begin{tabular}{|c|c|c|c|c|c|c|}
\hline entry & Ligand & $\mathrm{mol} \% \mathrm{~L}$ & solvent & temperature & time & yield $(\mathrm{GC})$ \\
\hline 1 & $53 b$ & 0.5 & $\mathrm{H}_{2} \mathrm{O}$ & $25^{\circ} \mathrm{C}$ & $14 \mathrm{~h}$ & $95 \%$ \\
\hline 2 & $\mathrm{PPh}_{3}$ & 0.5 & $\mathrm{H}_{2} \mathrm{O}$ & $25^{\circ} \mathrm{C}$ & $14 \mathrm{~h}$ & $74 \%$ \\
\hline 3 & $\mathbf{G}_{1}$ thia & 0.04 & $\mathrm{H}_{2} \mathrm{O}$ & $25^{\circ} \mathrm{C}$ & $14 \mathrm{~h}$ & $80 \%$ \\
\hline 4 & $\mathrm{G}_{1} \mathrm{PPh}_{2}$ & 0.04 & $\mathrm{H}_{2} \mathrm{O}$ & $25^{\circ} \mathrm{C}$ & $14 \mathrm{~h}$ & $78 \%$ \\
\hline 5 & $\mathbf{G}_{3}$ thia & 0.01 & $\mathrm{H}_{2} \mathrm{O}$ & $25^{\circ} \mathrm{C}$ & $14 \mathrm{~h}$ & $80 \%$ \\
\hline 6 & $\mathrm{G}_{3} \mathrm{PPh}_{2}$ & 0.01 & $\mathrm{H}_{2} \mathrm{O}$ & $25^{\circ} \mathrm{C}$ & $14 \mathrm{~h}$ & $75 \%$ \\
\hline 7.0 & $G_{1}$ thia & 0.04 & $\mathrm{H}_{2} \mathrm{O} / \mathrm{THF} 2: 5$ & $60^{\circ} \mathrm{C}$ & $24 \mathrm{~h}$ & $94 \%$ \\
\hline 7.1 & $G_{1}$ thia & 0.04 & $\mathrm{H}_{2} \mathrm{O} / \mathrm{THF} 2: 5$ & $60^{\circ} \mathrm{C}$ & $24 h$ & $95 \%$ \\
\hline 7.2 & $\mathrm{G}_{1}$ thia & 0.04 & $\mathrm{H}_{2} \mathrm{O} / \mathrm{THF} 2: 5$ & $60^{\circ} \mathrm{C}$ & $24 \mathrm{~h}$ & $96 \%$ \\
\hline 7.3 & $\mathbf{G}_{1}$ thia & 0.04 & $\mathrm{H}_{2} \mathrm{O} / \mathrm{THF} 2: 5$ & $60^{\circ} \mathrm{C}$ & $24 \mathrm{~h}$ & $94 \%$ \\
\hline 7.4 & $G_{1}$ thia & 0.04 & $\mathrm{H}_{2} \mathrm{O} / \mathrm{THF} 2: 5$ & $60^{\circ} \mathrm{C}$ & $24 \mathrm{~h}$ & $95 \%$ \\
\hline 8.0 & $\mathbf{G}_{1} \mathbf{P P h}_{2}$ & 0.04 & $\mathrm{H}_{2} \mathrm{O} / \mathrm{THF} 2: 5$ & $60^{\circ} \mathrm{C}$ & $24 \mathrm{~h}$ & $95 \%$ \\
\hline 8.1 & $\mathrm{G}_{1} \mathrm{PPh}_{2}$ & 0.04 & $\mathrm{H}_{2} \mathrm{O} / \mathrm{THF} 2: 5$ & $60^{\circ} \mathrm{C}$ & $24 \mathrm{~h}$ & $80 \%$ \\
\hline 8.2 & $\mathrm{G}_{1} \mathrm{PPh}_{2}$ & 0.04 & $\mathrm{H}_{2} \mathrm{O} / \mathrm{THF} 2: 5$ & $60^{\circ} \mathrm{C}$ & $24 \mathrm{~h}$ & $50 \%$ \\
\hline 8.3 & $\mathrm{G}_{1} \mathrm{PPh}_{2}$ & 0.04 & $\mathrm{H}_{2} \mathrm{O} / \mathrm{THF} 2: 5$ & $60^{\circ} \mathrm{C}$ & $24 \mathrm{~h}$ & - \\
\hline
\end{tabular}
greatly decreased by using the dendrimer supported thiazole phosphine ligand instead of the monomeric ligand, the final compounds containing less than 0.55 ppm Pd (Table 2, Entries 7. $x$ and 8.x correspond to recycling experiments).

Table 2. Suzuki reactions: synergistic effects of thiazoyl and diphenyl phosphino end groups grafted on the surface of phosphorus dendrimers of generation 1 and 3 .

All the results reported with these neutral or charged thiazoles $\mathrm{C}_{5}$ substituted by phosphines i.e. for ruthenium catalysed nitrile hydration reaction, copper-catalysed $\mathrm{N}$-arylation reactions, and Suzuki-type cross-coupling processes, clearly demonstrated the enormous potential of hetero aromatic thiazole phosphines for the development of new efficient and cleaner catalyst systems. Some examples of their metallo complexes are shown in Figures 8 and 9. 


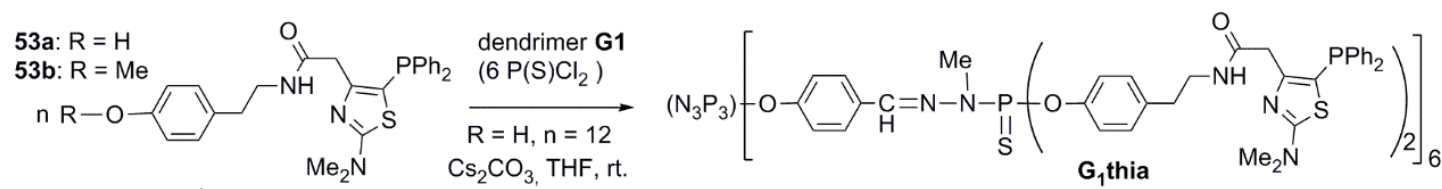

dendrimer $\mathbf{G} 3 \mid \mathrm{R}=\mathrm{H}, \mathrm{n}=48$ $\left(24 \mathrm{P}(\mathrm{S}) \mathrm{Cl}_{2}\right) \mid \begin{aligned} & \mathrm{R}=\mathrm{H}, \mathrm{n}=48 \\ & \mathrm{Cs}_{2} \mathrm{CO}_{3}, \text { THF, rt. }\end{aligned}$
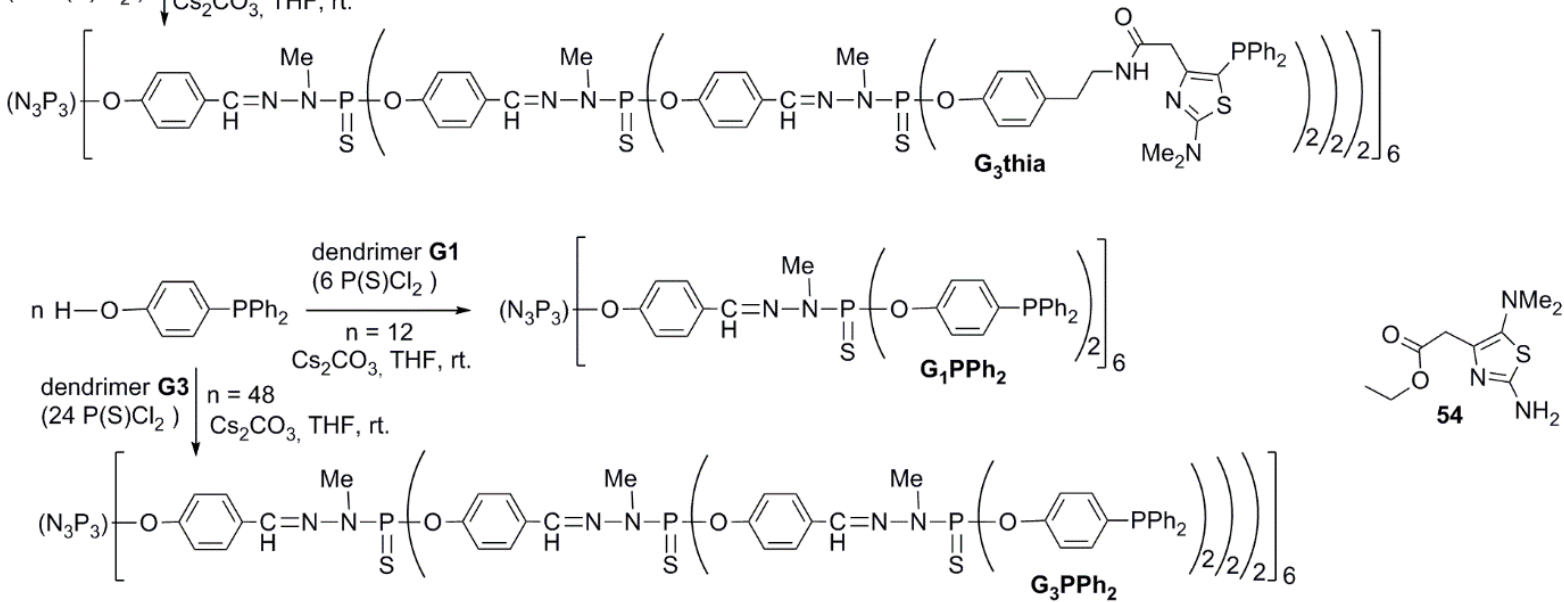

Scheme 24 Synthetic pathways for the synthesis of phosphorus dendrimers substituted with thiazole phosphine or triphenyl phosphine.<smiles>Cl[R1](Cl)(c1ccccc1)[PH](Cl)(c1ccccc1)c1nc2ccccc2s1</smiles>

55<smiles>Cc1ccc2sc(P(c3ccccc3)P(c3ccccc3)c3ccccc3)nc2c1</smiles>

$3 a$

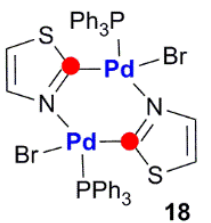

14
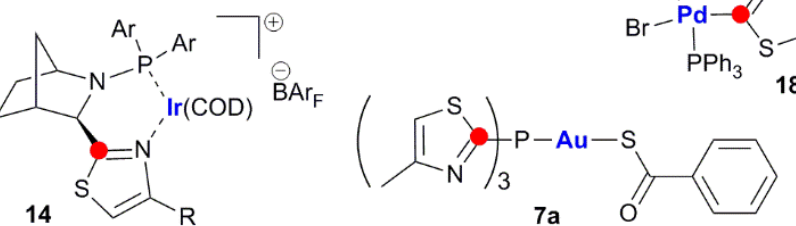

Fig. 8 Examples of $\mathrm{Ru},{ }^{15} \mathrm{Pt},{ }^{20} \mathrm{Pd},{ }^{27} \mathrm{Ir},{ }^{25}$ and $\mathrm{Au}^{21} \mathrm{C}_{2}$ thiazole phosphine complexes.
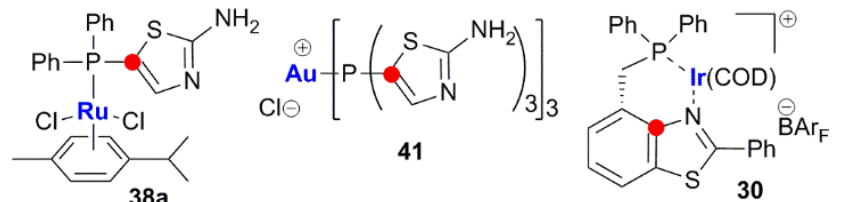

Fig. 9 Examples of $\mathrm{Ru}{ }^{45} \mathrm{Au},{ }^{39}$ and $\mathrm{Ir}^{28} \mathrm{C}_{5}$ and $\mathrm{C}_{4,5}$ thiazole phosphine complexes.

\section{Conclusions and Perspectives}

The rich chemistry which can be developed through $C_{2}, C_{4}, C_{4-5}$ and $C_{5}$ substitutions of the thiazole ring allows to prepare a large variety of thiazole and benzothiazole phosphines as efficient catalysts in a number of key organic reactions, and their corresponding $\mathrm{Ir}, \mathrm{Ru}, \mathrm{Pt}, \mathrm{Pd}, \mathrm{Cu}, \mathrm{Au}$ complexes, thus opening new perspectives of use in coordination chemistry and catalysis.
In addition, the recent progresses on 2-amino thiazoles and related compounds were highlighted in a recent review. ${ }^{58}$ Indeed, a number of drugs based on 2-aminothiazole (2-AT) core are in the market, e.g. Famotidine, Cefdinir, Meloxican, etc. and some other new 2-aminothiazoles have shown, antitumor, antidiabetic, and anticonvulsant activity. This should open an additional way of using thiazole and benzothiazole phosphonate and/or phosphines diversely substituted in medicinal chemistry and pharmacology. The illustrated possibility in this review of grafting metal on these ligands as well as the possibility to graft these ligands on the surface of phosphorus dendrimers offer exciting perspectives for biomedical applications. ${ }^{59-61}$

Medicinal chemistry which encompasses the design and the synthesis of novel bioactive compounds needs new chemical scaffolds as highlighted by Taylor et al. ${ }^{62}$ Indeed, the 1,175 drugs commercially available before 2013 have only 351 unique ring system, representing $2 \%$ of combination between monocyclic and bicyclic rings. In addition, only six new ring systems have been described each year. Consequently, the need of novel heterocycles appears to be crucial. We are convinced that this review will be a good help for scientists involved in different areas of chemistry including new methodologies of synthesis, coordination chemistry, catalysis, medicinal chemistry, i.e. fields of research which will take profit of the versatile ways of preparation of new thiazole and benzothiazole derivatives as well as the versatility of their chemical behaviour.

\section{Conflicts of interest}

There are no conflicts to declare. 


\section{Acknowledgements}

Thanks are due to the CNRS for financial support.

\section{References}

1 P.K. Sharma, S.N. Sawnhey, A. Gupta, G.B. Singh and S. Bani, Indian J. Chem., 1998, 37B, 376-381.

2 A.M. Khalil, M.A. Berghot and M.A. Gouda, Eur .J. Med. Chem., 2009, 44, 4434-4440.

3 K.D. Kargrave, F.K. Hess and J.T. Oliver, J. Med. Chem., 1983, 26, 1158-1163.

4 W.C. Patt, H.W. Hamilton, M.D. Taylor, M.J. Ryan, D.G Taylor, C.J.C. Connolly, A. Doherty, S.R. Klutchko, I. Sircar, B.A. Steinbaugh, B.L. Batley, C.A. Painchaud, S.T. Rapundalo, B.M. Michniewicz and S.C.J. Olson, J. Med. Chem., 1992, 35 2562-2572.

5 N. Ergenc, G. Capan, N.S. Gunay, S. Ozkirimli, M. Gungor, S. Ozhey and E. Kendi, Arch. Pharm., 1999, 332, 343-347.

6 J.C. Jaen, L.D. Wise, B.W. Caprathe, H. Tecle, S. Bergmeier, C.C. Humblet, T.G. Heffner, L.T. Meltzner and T.A. Pugsler, J. Med. Chem., 1990, 33, 311-317.

7 J. Rudolph, H. Theis, R. Hanke, R. Endermann, L. Johannsen and F.U. Geschke, J. Med. Chem., 2001, 44, 619-626.

8 A. Bador, M.F. Bordes, P. De Coointet, P. Savi, A. Bernat, A Lale, M. Petitou, J.P. Maffrand and J.M. Herbert, J. Med. Chem., 1997, 40, 3393-3401.

9 P.C. Sharma, A. Sinhmar, A. Sharma, H. Rajak and D.P. Pathak, J. Enzyme Inhibition and Med. Chem., 2013, 28, 1-10.

10 D. Das, P. Sikdar and M. Bairagi, Eur. J. Med. Chem., 2016 $109,89-98$

11 L. Hroch, L. Aitken, O. Benek, M. Dolezal, K. Kuca, F. GunnMoore and K. Musilek, Curr. Med. Chem., 2015, 22, 730-747.

12 A. Kamel, M.A.H. Syed and S.M. Mohammed, Expert Opinion on Therapeutic Patents, 2015, 25, 335-349.

13 X.L. Chen, X. Li, L.B. Qu, Y.C. Tang, V.P. Mai, D.H. Wei, W.Z. $\mathrm{Bi}$, L.K. Duan, K. Sun, J.Y. Chen, D.D. Ke and Y.F. Zhao, J. Org. Chem., 2014, 79, 8407-8416.

14 C. Hou, Y. Ren, R. Lang, X. Hu, C. Xia and F. Li, Chem. Commun., 2012, 48, 5181-5183.

15 H.J. Zhang, W. Lin, Z. Wu, W. Ruan and T.B. Wen, Chem. Commun., 2015, 51, 3450-3453.

16 K. Luo, Y.Z. Chen, W.C. Yang, J. Zhu and L. Wu, Org. Lett., 2016, 18, 452-455.

17 K. Luo, Y.Z. Chen, K.L.X. Chen and L. Wu, J. Org. Chem., 2016, 81, 4682-4689.

18 L. Li, J.J. Wang and G.W. Wang, J. Org. Chem., 2016, 81, 5433-5439.

19 W. Lin, F. Su, H.J. Zhang and T.B. Wen, Eur. J. Org. Chem., 2017, 1757-1759.

20 S.S. Moore and G.M. Whitesides, J. Org. Chem., 1982, 47, 1489-1493.

21 C.E. Strasser, W.F. Gabrielli, C. Esterhuysen, O.B. Schuster S.D. Nogai, S. Gronje and H.G. Raubenheimer, New J. Chem. 2008, 32, 138-150.

22 A. Neveling, G.R. Julius, S. Cronje, C. Esterhuysen and H.G. Raubenheimer, Dalton Trans., 2005, 181-192.

23 T.K. Olszewski and B. Boguszek, Tetrahedron, 2010, 66, 86618666.

24 T.K. Olszewski, B. Boguszek, S. Sobek and H. Kozlowski, Tetrahedron, 2006, 62, 2183-2189.

25 J.Q. Li, A. Paptchikhine, T. Govender and P.G. Andersson, Tetrahedron: Asym., 2010, 21, 1328-1333.

26 M. Biosca, A. Paptchikhine, O. Pàmies, P.G. Andersson and M. Diéguez, Chem. Eur. J., 2015, 21, 3455-3464.

27 K-H. Yih, H-F. Wang and Gu Lee, J. Chinese Chem. Soc., 2007, 54, 553-558.
28 C. Hedberg, K. Kallstrom, P. Brandt, L.K. Hansen and P.G. Andersson, J. Am. Chem. Soc., 2006, 128, 2995-3001.

29 A. Paptchikline, P. Cheruku, M. Engman and P.G. Andersson, Chem. Commun., 2009, 5996-5998.

30 P. Cheruku, T.L. Church, A. Trifonova, T. Wartmann and P.G. Andersson, Tet. Letters, 2008, 49, 7290-7293.

31 Q. Dang, Y. Liu, D.K. Cashion, S. R. Kasibhatla, T. Jiang, F. Taplin, J.D. Jacintho, H. Li, Z. Sun, Y. Fan, J. DaRe, F. Tian, W. Li, T. Gibson, R. Lemus, P.D. van Poelje, S.C. Potter and M.D. Erion, J. Med. Chem., 2011, 54, 153-165.

32 P. Kaukoranta, K. Kallstrom and P.G. Andersson, Adv. Synth Catal., 2007, 349, 2595-2602.

33 P. Cheruku, A. Paptchikhine, M. Ali, J.M. Neudorfl and P. G. Andersson, Org. Biomol. Chem., 2008, 6, 366-373.

34 G.V. Oshovskii, A.A. Tolmachev, A.A. Yurchenko, A.S Merkulov and A.M. Pinchuk, Russ. Chem. Bull., 1999, 48, 1341-1346.

35 A.M. Pinchuk, A.A. Yurchenko, G.V. Oshovsky, E.V. Zatrudnitskii, A.O. Pushechnikov and A.A. Tolmachev, Pol. J. Chem., 2001, 75, 1137-1140.

36 G.V. Oshovskii, A.A. Tolmachev, A.S. Merkulov and A.M. Pinchuk, Khim. Geterotsikl. Soedin., 1997, 1422-1424.

37 S. Merino, L. Brauge, A.M. Caminade, J.P. Majoral, D. Taton and Y. Gnanou, Chem. Eur. J., 2001, 7, 3095-3105.

38 N. Katir, N. El Brahmi, A. El Kadib, S. Mignani, A.M. Caminade, M. Bousmina and J.P. Majoral, Chem. Eur. J., 2015, 21, 6400-6408.

39 M. Zablocka, G. Oshovsky, C. Duhayon, S. Ladeira, A.M. Caminade, S. Mignani and J.P. Majoral, Dalton Trans., 2016, 45, 9695-9703.

40 R. Kolodziuk, A. Penciu, M. Tollabi, E. Framery, C. GouxHenry, A. lourtchenko and D. Sinou, J. Organomet. Chem. 2003, 687, 384-391.

41 G.V. Oshovsky. A. Quali N. Xia, M. Zablocka, R.T. Boere, C. Duhayon, M. Taillefer and J.P. Majoral, Organometallics, 2008, 27, 5733-5736.

42 A.D. Phillips, L. Goncalvi, A. Romerosa, F. Vizza and M. Peruzzini, Coord. Chem. Rev., 2004, 248, 955-993.

43 A.E. Diaz-Alvarez, P. Crochet, M. Zablocka, C. Duhayon, V. Cadierno, J. Gimeno and J.P. Majoral, Adv. Synth. Catal. 2006, 348, 1671-1679.

44 J.P. Majoral, R. Kraemer, J. Navech and F. Mathis, Tet Letters, 1975, 1484-1487.

45 R. Gracia-Alvarez, M. Zablocka, P. Crochet, C. Duhayon, J.P. Majoral and V. Cadierno, Green Chem., 2013, 15, 2447-2456.

46 See for example: A. Balanta, C. Godard and C. Claver, Chem. Soc. Rev., 2011, 40, 4973-4985.

47 P. Servin, R. Laurent, A. Romerosa, M. Perruzzini, J.P. Majora and A.M. Caminade, Organometallics, 2008, 27, 2066-2073.

48 A. M. Caminade, A. Ouali, M. Keller and J.P. Majoral, Chem Soc. Rev., 2012, 41, 4113-4125.

49 A.M. Caminade, P. Servin, R. Laurent and J.P. Majoral, Chem Soc. Rev., 2008, 37, 56-67.

50 A. Ouali, R. Laurent, A.M. Caminade, J.P. Majoral and M Taillefer, J. Am. Chem. Soc., 2006, 128, 15990-15991.

51 G. Jayamurugan and N. Jayaraman, Adv. Synth. Catal., 2009, 351, 2379-2390.

52 J. Liu, Y. Feng, Y. He, N. Yang and Q.H. Fan, New J. Chem. 2012, 36, 380-385

53 D.J.M. Snelders, G. van Koten and R.S.J.M. Klein Gebbink, J. Am. Chem. Soc., 2009, 131, 11407-11416.

54 M. Janssen, C. Muller and D. Vogt, Adv. Synth. Catal., 2009, 351, 313-318

55 M. Meise and R. Haag, ChemSusChem, 2008, 1, 637-642.

56 See for example: A. Fihri, M. Bouhara, B. Nekoueishahraki, J.M. Basset and V. Polshettiwar, Chem. Soc. Rev., 2011, 40, 5181-5203. 
57 M. Keller, A. Hameau, G. Spataro, S. Ladeira, A.M. Caminade, J.P. Majoral and A. Ouali, Green Chem., 2012, 14, 2807-2815.

58 D. Das, P. Sikdar and M. Bairagi, Eur. J. Med. Chem., 2016, 109, 89-98.

59 S. Mignani, N. El Brahmi, T. Cresteil and J.P. Majoral, Oncology, 2018, 94, 324-328.

60 S. Mignani, N. El Brahmi,S. El Kazzouli, R. Laurent, S. Ladeira, A.M. Caminade, E. Pedziwiatr-Werbicka, E.M. Szewczyk, M. Eligia, M. Bryszewska, M.M. Bousmina, T. Cresteil and J.P. Majoral, Mol. Pharmaceutics, 2017, 14, 4087-4097.

61 S. Mignani, N. El Brahmi, L. Eloy, J. Poupon, V. Nicolas, A. Steinmetz, S. Kazzouli, M.M. Bousmina, M. Blanchard-Desce, A.M. Caminade, J.P. Majoral and T. Cresteil, Eur. J. Med. Chem., 2017, 132, 142-156.

62 R. D. Taylor, M. MacCoss and A.D. Lawson, J. Med. Chem., 2017, 60, 1638-1647. 